\title{
BMJ Global Health National health governance, science and the media: drivers of COVID-19 responses in Germany, Sweden and the UK in 2020
}

\author{
Claudia Hanson (D) , ,,2 Susanne Luedtke, ${ }^{3,4}$ Neil Spicer, ${ }^{5}$ Jens Stilhoff Sörensen, ${ }^{6}$ \\ Susannah Mayhew, ${ }^{7}$ Sandra Mounier-Jack ${ }^{7}$
}

To cite: Hanson C, Luedtke S, Spicer N, et al. National health governance, science and the media: drivers of COVID-19 responses in Germany, Sweden and the UK in 2020. BMJ Global Health 2021;6:e006691. doi:10.1136/ bmjgh-2021-006691

Handling editor Seye Abimbola

- Additional supplemental material is published online only. To view, please visit the journal online (http://dx.doi.org/10. 1136/bmjgh-2021-006691)

Received 22 June 2021 Accepted 17 October 2021

\section{ABSTRACT}

The COVID-19 pandemic is an unprecedented global crisis in which governments had to act in a situation of rapid change and substantial uncertainty. The governments of Germany, Sweden and the UK have taken different paths allowing learning for future pandemic preparedness. To help inform discussions on preparedness, inspired by resilience frameworks, this paper reviews governance structures, and the role of science and the media in the COVID-19 response of Germany, Sweden and the UK in 2020. We mapped legitimacy, interdependence, knowledge generation and the capacity to deal with uncertainty. Our analysis revealed stark differences which were linked to pre-existing governing structures, the traditional role of academia, experience of crisis management and the communication of uncertainty-all of which impacted on how much people trusted their government. Germany leveraged diversity and inclusiveness, a 'patchwork quilt', for which it was heavily criticised during the second wave. The Swedish approach avoided plurality and largely excluded academia, while in the UK's academia played an important role in knowledge generation and in forcing the government to review its strategies. However, the vivant debate left the public with confusing and rapidly changing public health messages. Uncertainty and the lack of evidence on how best to manage the COVID-19 pandemic - the main feature during the first wave-was only communicated explicitly in Germany. All country governments lost trust of their populations during the epidemic due to a mix of communication and transparency failures, and increased questioning of government legitimacy and technical capacity by the public.

\section{INTRODUCTION}

The COVID-19 pandemic is an unprecedented global crisis. Reported cumulative global cases and deaths were 83 and 1.8 million, respectively, at the end of 2020 , and Europe accounts for around one-third of global cases and deaths. ${ }^{1}$ European countries were insufficiently prepared when a large COVID-19 outbreak in northern Italy first became evident. $^{2}$

\section{WHAT IS ALREADY KNOWN?}

$\Rightarrow$ Governments in Europe reacted in different ways to the COVID-19 crisis; the Swedish exception has raised debate.

$\Rightarrow$ Little is known, however, how differences in the pandemic handling related to government structures the role of academia and the communication with the public.

\section{WHAT ARE THE NEW FINDINGS?}

$\Rightarrow$ Germany, Sweden and the UK responded in a very different way in line with the (i) pre-existing societal and academic culture, (ii) the existence of trusted academic advisory boards and (iii) the ability to manage and leverage diversity allowing broad academic involvement and societal debate.

$\Rightarrow$ Germany leveraged diversity and inclusiveness and allowed a broad societal debate, but this overwhelmed the population in the second wave.

$\Rightarrow$ Sweden feared different views: the government instead delegated the handling of the pandemic to the Public Health Agency.

$\Rightarrow$ The UK leveraged its strong academic structures, but the public was left with confusing and rapidly changing public health messages.

\section{WHAT DO THE NEW FINDINGS IMPLY?}

$\Rightarrow$ Pandemic preparedness will need to go beyond traditional approaches to preparedness within the health sector and state emergency function.

$\Rightarrow$ Strong pre-existing, trusted and functional academic and public advisory bodies that can support decision-making, evidence creation as well as communication with and engagement of the public may increase resilience-but these structures can only be fully leveraged if politicians and the media are able to provide them space.

Governments were forced to respond to a crisis characterised by many uncertainties, especially relating to levels of presymptomatic transmission $^{34}$ and infection-fatality rates. ${ }^{5}$ Interventions to address the epidemic were 
first based on practices used to curb common influenza epidemics including handwashing. The use of masks was adopted, but only hesitantly at first. When the second wave hit Europe in autumn 2020, uncertainty was substantially reduced. In early November, consensus emerged on infection-fatality rates, with estimates ranging from $0.4 \%^{6}$ to $0.8 \%$ across European countries, ${ }^{78}$ confirming higher levels than in typical influenza epidemics. ${ }^{9}$ There was broad consensus at that time on the importance of transmission through smaller airborne droplets (aerosols), the importance of presymptomatic and asymptomatic infection transmission ${ }^{10}$ and more clarity about the role of infection and transmission in children. ${ }^{112}$ In the midst of the second wave, news about the imminent availability of effective vaccines was released.$^{13}$ Soon after, new mutations discovered in the UK and South Africa curtailed hopes that the pandemic could be tackled within a few months; again this raised uncertainty.

Government decision-making in such a crisis, particularly when scientific uncertainty is high, demands capacity and legitimacy to protect citizens as well as health systems. ${ }^{14}$ Concepts of health systems resilience-the capacity to adapt and respond to shocks-have been discussed and framed in recent years. This includes critical consideration in reducing the negative and often unequal effects on health that can result from crises. ${ }^{15}$ Discussions about system resilience emerged during and after the 20132016 West Africa Ebola outbreak. That time evidence was created-although often ignored-on the importance of health systems being adaptable to sudden crises, ${ }^{16} 17$ contributing to thinking on how systems could also adapt to longer-term challenges such as climate change. ${ }^{818}$ Subsequently, a larger body of evidence has been gathered to better conceptualise and refine the concept of health system resilience, and studies are beginning to use this concept to analyse systems responses to outbreaks. ${ }^{19} 20$ Few have applied resilience as a lens for the analysis of governance and government decision-making in crises to review the relevance of the domains. ${ }^{21}$ Yet, the COVID-19 crisis highlights the importance of governance of the health systems and health. ${ }^{22}$ The importance of assessing processes, including communication, building legitimacy and creating knowledge in the population, in addition to focussing on outcomes such as morbidity and mortality, cannot be overemphasised. ${ }^{23}$

After over 1 year into the COVID-19 pandemic, several scholars have started to rank country performance. Within Europe large differences in excess mortality has been described for 2020. ${ }^{24}$ The Bloomberg Resilience Score takes a more holistic approach and includes in addition to mortality also social freedom, vaccination and other indicators describing the ability to go back to noramality. ${ }^{25}$ The ranking of better and worse performers raises the question of factors and processes which made countries to be more or less successful. Those countries, including Sweden and the UK, which scored highest on Global Health Security Index-a six-category score encompassing aspects of detection and reporting, rapid response and health systems readiness-did not demonstrate an effective response, raising questions about aspects of crisis readiness that were missed in the score. ${ }^{26} 27$

To support the further conceptualisation of potential factors which increase epidemic preparedness and increase societal and health systems resilience we use the Blanchet et al resilience framework to better understand the COVID-19 response and particularly governance and leadership, the link to science, and how this shaped communication with populations leading to enhanced or damaged inclusion and trust. Further, we aimed to contribute to theoretical reflections on governance and resilience and how to better frame necessary processes and decision-making to strengthen future crisis management and pandemic preparedness. ${ }^{28}$

We selected the three countries on the European continent of Germany, Sweden and the UK because the (i) were being hit at virtually the same time in 2020 but (ii) adopted very distinct approaches to the first and second wave. Germany was early characterised as wellperforming. ${ }^{29}$ The Swedish exceptionalism was unique in Europe and has raised much international debate. ${ }^{30}$ The UK has a strong academic public health tradition and UK based researchers were publishing important background papers, ${ }^{31}{ }^{32}$ yet COVID-19 mortality rates were high and its response to the first wave was heavily criticised. COVID-19 mortality rates differ strongly between the three countries in the first and second wave and differences are still seen. ${ }^{33}$

\section{METHODS AND CONCEPTUAL FRAMING}

We analysed governance, policies and communication of the governments of Germany, Sweden and the UK, informed by the resilience framework of Blanchet et $a l^{34}$ with additional adjustments relating to cross-cutting dimensions as hypothesised by Hanefeld et al. ${ }^{15}$ The domains within our framework (figure 1) are supported by governance scholarship ${ }^{145}$ and are particularly relevant for thinking about health crisis management, and hence for conceptualising key issues that have arisen during the COVID-19 pandemic. In particular the framework reflects the importance of (i) legitimacy of governance and decision-making, ${ }^{13}$ (ii) knowledge creation and communication, particularly when there is scientific uncertainty and (iii) collaboration with as well as interdependence between the community and other actors including scientists and the media. ${ }^{36}$

We populated the original elements with information from the three countries. Specifically, we mapped legitimacy, interdependence, knowledge generation and the capacity to deal with uncertainty. Our analysis describes the capacity of these countries to manage the crisis in 2020.

The paper is based on a systematic document and policy analysis. ${ }^{37}$ However, while we sought to directly compare the three countries, in practice it was necessary 
- Official communication including key messages

- Knowledge generation

- Inclusion of other institutions

- Media and other channels

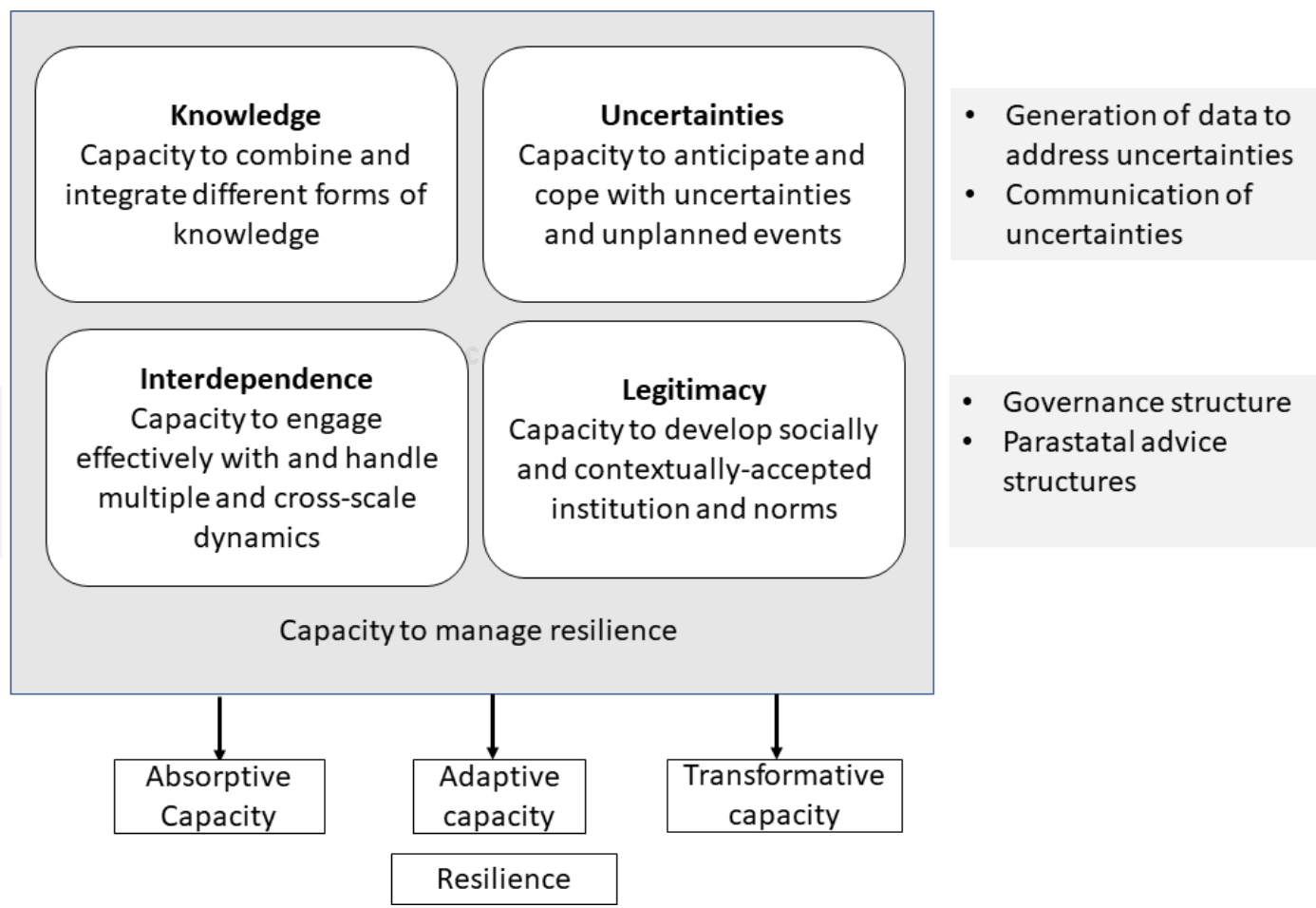

Figure 1 Resilience framework to assessing government responses to COVID-19 (adapted from Blanchet et a/ ${ }^{34}$ ).

and appropriate to adopt a flexible approach when identifying the documents that we drew on. This was because the sources of information on COVID-19 varied substantially between the countries. Also, the nature of the pandemic, the policy resources and sources of information changed very rapidly throughout 2020.

Much of the information we used was drawn from government and public health Agency websites of countries' public health agencies and governments: the Robert Koch Institute, Germany, ${ }^{38}$ the Public Health Agency (PHA), Sweden, ${ }^{39}$ and the Coronavirus (COVID19) page of the UK government (Gov.UK). ${ }^{40}$ We also included mass media websites. A list of websites searched and keywords used is provided in online supplemental web annex 1. We analysed the policies of the countries in relation to each domain of our framework. Information was cross-checked with already published work and carefully referenced to ensure transparency.

We reconstructed the timeline of events and interventions from government websites and mass media and extracted data on the 14-day rolling average of cases, deaths and SARS-CoV-2 testing from the European Centre for Disease Prevention and Control (ECDC) ${ }^{33}$ except for the UK testing data for which we extracted data from the government homepage of England, Wales, Scotland and Northern Ireland and calculated weekly rates per population. ${ }^{40}$ We used the COVID-19 Government Response Stringency Index, ${ }^{41}$ to assess the strength of the government intervention in each country. We used the YouGov COVID-19 tracker to summarise levels of trust by plotting the answers to the question of whether respondents agree that the government handled the coronavirus 'very' and 'somewhat well'. ${ }^{42}$ We imputed missing data points using the impute command in Stata V. 16.

\section{RESULTS}

\section{Timeline of the pandemic and the response}

All three countries detected their first cases of SARS-CoV-2 in January 2020 which triggered their first responses, but they only started to act more decisively when community transmission became apparent in the three countries in early March (figure 2A-C, online supplemental file 4).

Both Germany and the UK responded on 23 March with national restrictions, although of different intensity. Educational, leisure and cultural facilities were closed in both countries. The UK instituted strict 'stay-at-home' orders, while Germany allowed people to meet outside. In contrast, Sweden's public life remained less interrupted. Schools remained open, although the last three grades moved to distance learning. Also, large events were banned. Given the fast and more restrictive reaction of other Nordic countries, the PHA's strategy came in for early criticism by some. ${ }^{43}$

Cases started to decline in mid-April in Germany and the UK at which point measures were relaxed and public life partly restored, and schools were reopened. In contrast, there were only minimal changes in Sweden where less stringent measures remained including a ban of larger events. Germany and the UK had very low numbers of cases of just 6 (Germany) and 12 (UK) over a 14-day rolling average per 100000 population in June and July 2020, while in Sweden cases were never reduced below 25 infections in 14-days per 100000 population. 


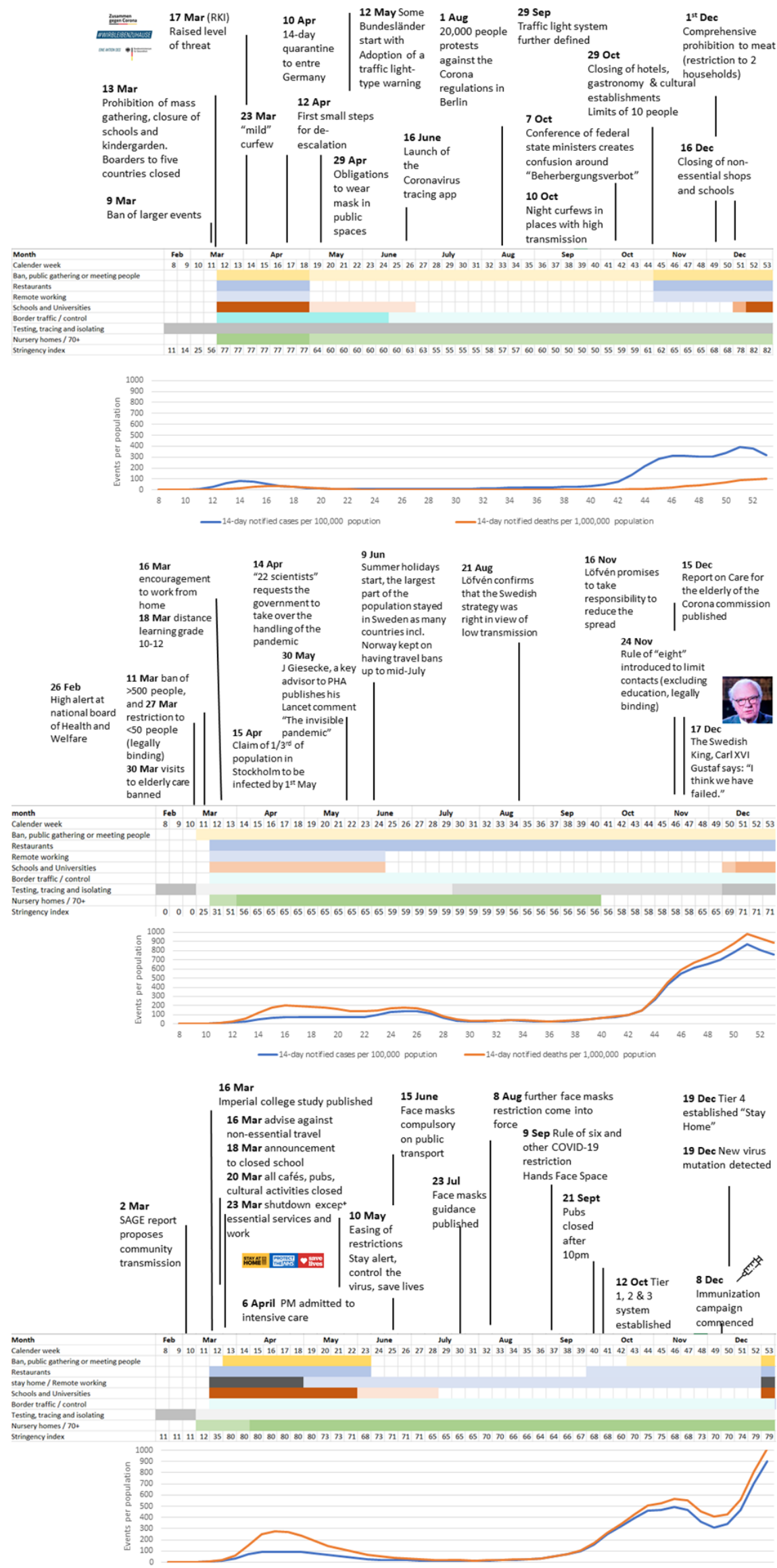

Figure 2 (A-C) Timeline of responses in Germany, Sweden and the UK (February-December 2020) (online supplemental web annex 2 references to timeline). 
Schools in all three countries reopened in autumn 2020 for the new school year.

In the UK, the second wave started to become apparent in late September, which was about 10 days earlier than in Germany and Sweden. In Germany, a circuit breaker, including closing cafes, restaurants and cultural activities was implemented. Cases stabilised but did not decline, which lead the government to close non-essential shops and institute home-schooling by mid-December. In Sweden, the increase in cases in October took the population and government by surprise, given that the PHA had repeatedly stated Sweden would be less severely hit because of the larger spread in the spring of 2020.

In the UK, and similarly in Germany, softer control measures were initially introduced during the second wave. At the start of December, relaxation measures were implemented until a new lockdown was enacted later that month when new variant strains started to emerge and spread in the build up to Christmas.

\section{INTERDEPENDENCY AND LEGITIMACY Governance set-up}

Throughout the first and second wave, in both Germany and the UK, the elected federal and national governments led the response. In contrast, the Swedish national government, although formally responsible, were little visible in the public and rather entrusted leadership to the PHA. These institutions had different levels of public and legal legitimacy and different sets of interdependencies (table 1). In Germany and the UK, emergency powers were enacted in March 2020 through Infection Protection Acts. In Sweden, a COVID-19 emergency law was passed only in January 2021.

As a federal state, Germany installed a coordinating and decision-making body headed by Chancellor Merkel which included all heads of its regional states. This allowed strong locally adapted action. In Sweden, no national crisis management programme was activated. The UK, as a union of four nations, initially pursued aligned unified approach through ministerial implementation. This gradually diverged in the second wave, with responses more strongly led by the devolved administrations of England, Scotland, Wales and Northern Ireland. Hence, the UK nations increasingly implemented their own specific measures and timetables based on the local epidemiological situation and political context. ${ }^{44}$ For example, Wales instituted a circuit breaker during the school holidays, Scotland closed the borders before Christmas and England introduced a three-tiered system of restrictions.

Interdependency: inclusion of scientific bodies and seeking advice Interdependence between the policymaking structures and academia was established in different ways. Germany relied on existing legal structures such as its parastatal Robert Koch Institute, the Ethics Advisory Board and its wide network of independent research institutions.
Consultations with other scientists were demand-based and not part of a predefined scheme.

The UK used and expanded on its pre-existing national scientific committee, the Scientific Advisory Board for Emergencies (SAGE). SAGE became very influential: the lockdown implemented on March 2020 was said to have been a direct response to a modelling paper provided by a member of SAGE. ${ }^{31}$ SAGE was initially contested because of a lack of transparency of its membership, but remained influential because of its wide academic membership and remit and the role of its members in directly communicating evidence to the media and the wider public.

While the UK had traditionally strong independent public health agencies, Public Health England (PHE) had already lost much of its autonomy and independence with the demise of its predecessor, the Health Protection Agency. The present government opted for a stronger inclusion of the private sector and shifted the testing and tracing strategy and delivery away from PHE. ${ }^{45}$ The prime ministers' office was also preoccupied with Brexit and other priorities and appeared unprepared to listen to academia. ${ }^{32}$

In Sweden, the PHA, in line with their mandate, led on health protection-related policies on behalf of the government. A formal advisory board was instituted in April 2020 after criticism of the dominance of PHA emerged, but no minutes or meeting agendas were made publicly available. ${ }^{46}$

\section{Interdependency: media}

In Germany, print media, public television and radio played a large role in communication and information sharing. Both public TV channels ARD and ZDF, provided ample space for intensive information and debate of several hours per week (online supplemental file 3). Mainstream as well as critical voices opposing the main government strategies were invited. The inclusion of multiple voices, including virologists and epidemiologists, together with politicians and other members of civil society, economists, political scientists, philosophers and ethicists enabled the public to follow the complexity of decision-making. The innovative format of a daily podcast with Christian Drosten from Charité was launched on 26 February 2020 and is still running with over 50 million listeners ${ }^{47}$ and has received prizes. ${ }^{48}$

In Sweden, daily press conferences gave the PHA ample space to report. Public television provided very few opportunities for scientists to contribute to the national conversation. Only seven debates were included in the public television. However, there was debate in the daily newspapers. The UK, however, had extensive COVID-19 media coverage, across all types of media and surveys showed that the majority of the public relied on the mass media for information about COVID-19. ${ }^{49}$ 


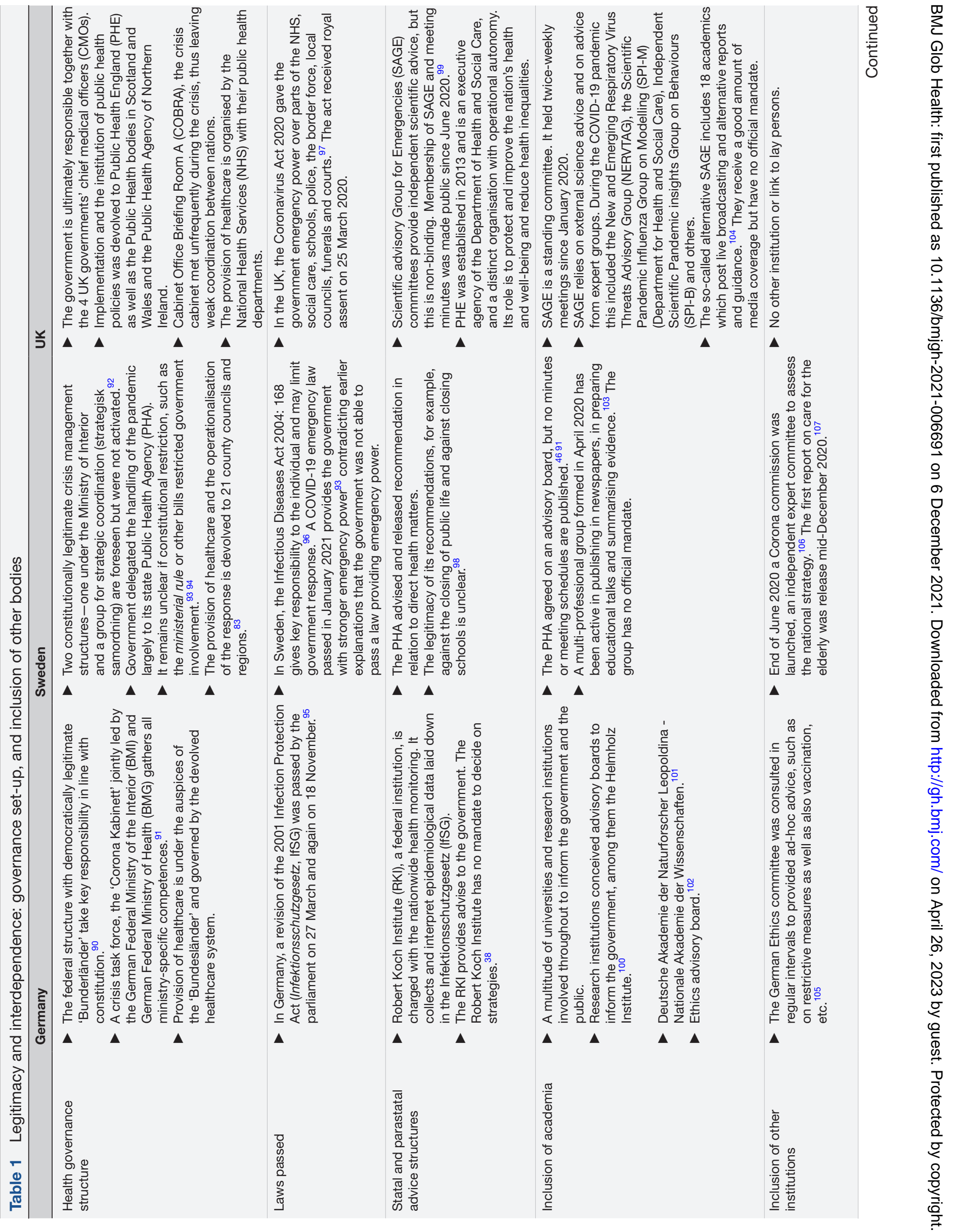




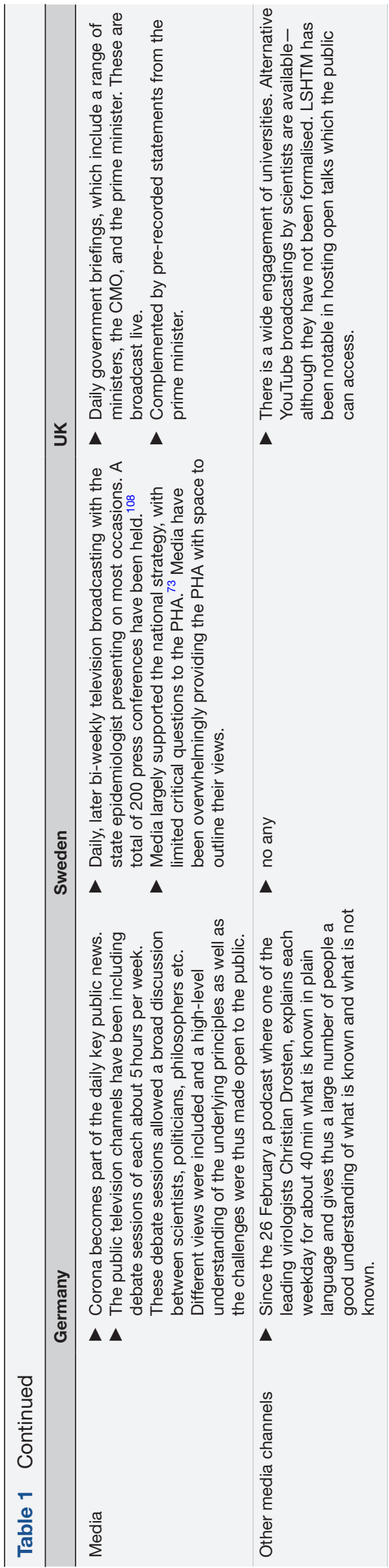

Knowledge generation and dealing with uncertainty Knowledge: generation of data

Data needed for monitoring the pandemic were provided by the public health agencies in Germany and Sweden. Daily or weekly reports were made public. Germany scaled-up testing rapidly during the first wave, although hit capacity limitations similar to those of Sweden and the UK in the second wave (table 2, online supplemental file 4). In the UK, the Test, Track and Trace system was outsourced to the private sector from April 2020. This led initially to there being insufficient sites and poor geographical distribution with insufficient data to ensure locally targeted approaches with local involvement. ${ }^{50}$ However, the UK's academic public health structures with government research funding made it possible within a short time to set up national population-based surveys such as the SARS-CoV-2 Infection and Immunity Survey and the Covid Symptom Study. Neither Germany nor Sweden had such established surveillance systems although there were smaller, local surveys.

\section{Knowledge: communication with the public}

Public messaging in all three countries focused on hand hygiene and social distancing during the first wave (table 2). In view of the evolving evidence, additional messages were added in Germany such as the use of face coverings and later opening of windows in line with evolving evidence. In contrast, messages remained the same in Sweden and were limited to hygiene and social distancing. In the UK, key slogans changed multiple times in 2020 from 'stay at home' (March), 'stay alert' (May) to V-day (December). Protecting the health systems from being overwhelmed were key objectives in all three countries. Clear targets, such as an incidence rate of below 50 infections per week per 100000 population were only set in Germany, although at a somewhat arbitrary level, but supported by modelling arguments to prevent the testing, tracing and isolating system from being overwhelmed. ${ }^{51}$

Uncertainty: dealing with uncertainty while creating trust

A particular feature of the German response was the repeated communication of uncertainty (table 2), which made it substantially easier to adapt messages over time. While the UK and Sweden claimed early on to base their approach on science and evidence, politicians in Germany repeatedly stressed they had limited information to inform their decisions: indeed, the German Health Minister Spahn expressed this in April 2020 in a speech widely reported by the media. ${ }^{52}$ In Sweden, the communication of uncertainty was perceived as inappropriate given that it could raise fear. ${ }^{53}$ The PHA repeatedly stated to base their recommendations on evidencehowever, critical voices challenged this in view of the evolving evidence. ${ }^{53} 54$

Figure 3 shows data on how populations rated their government response using the YouGov COVID-19 tracker. In all three countries, people had more confidence in their government during the first wave than 


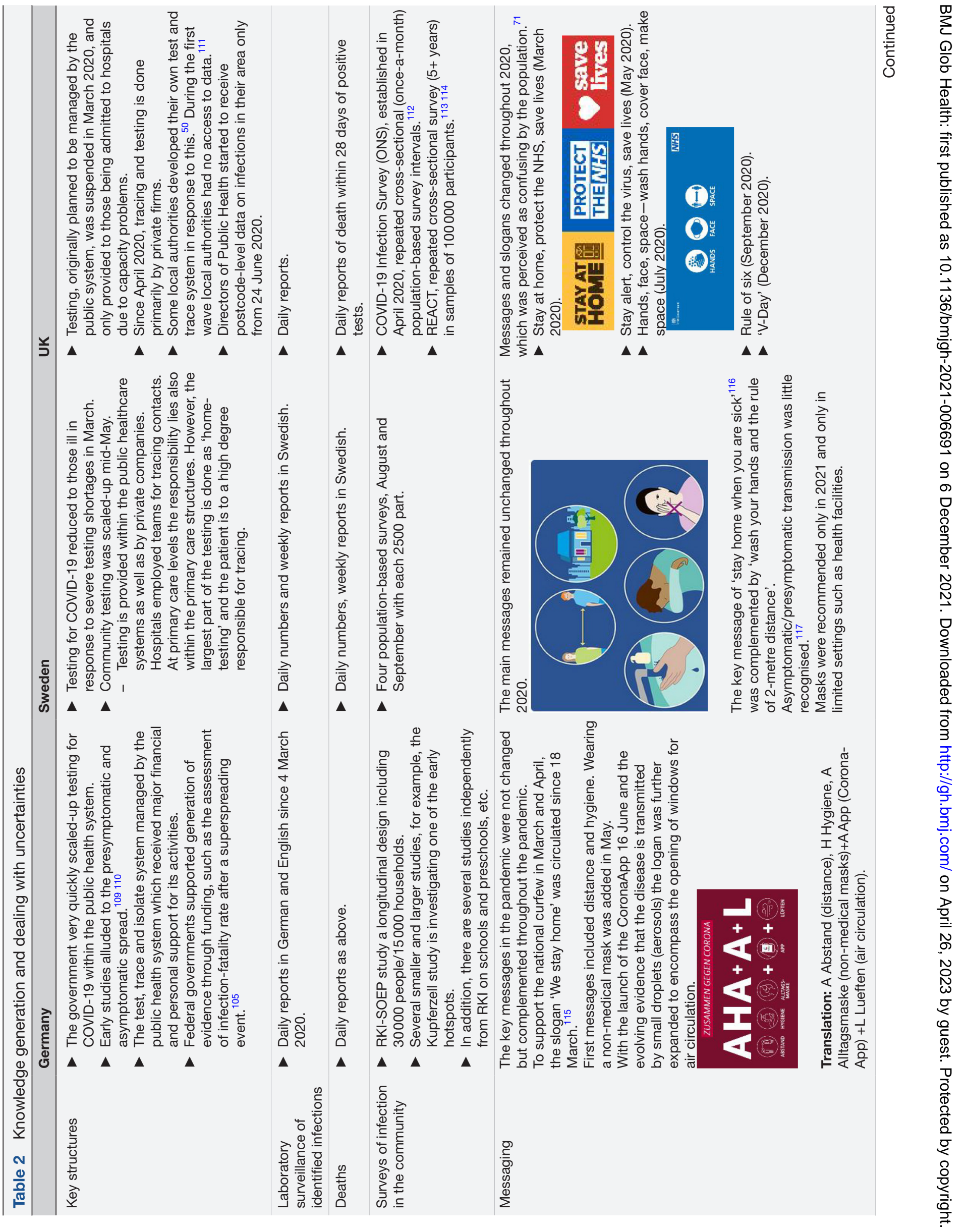




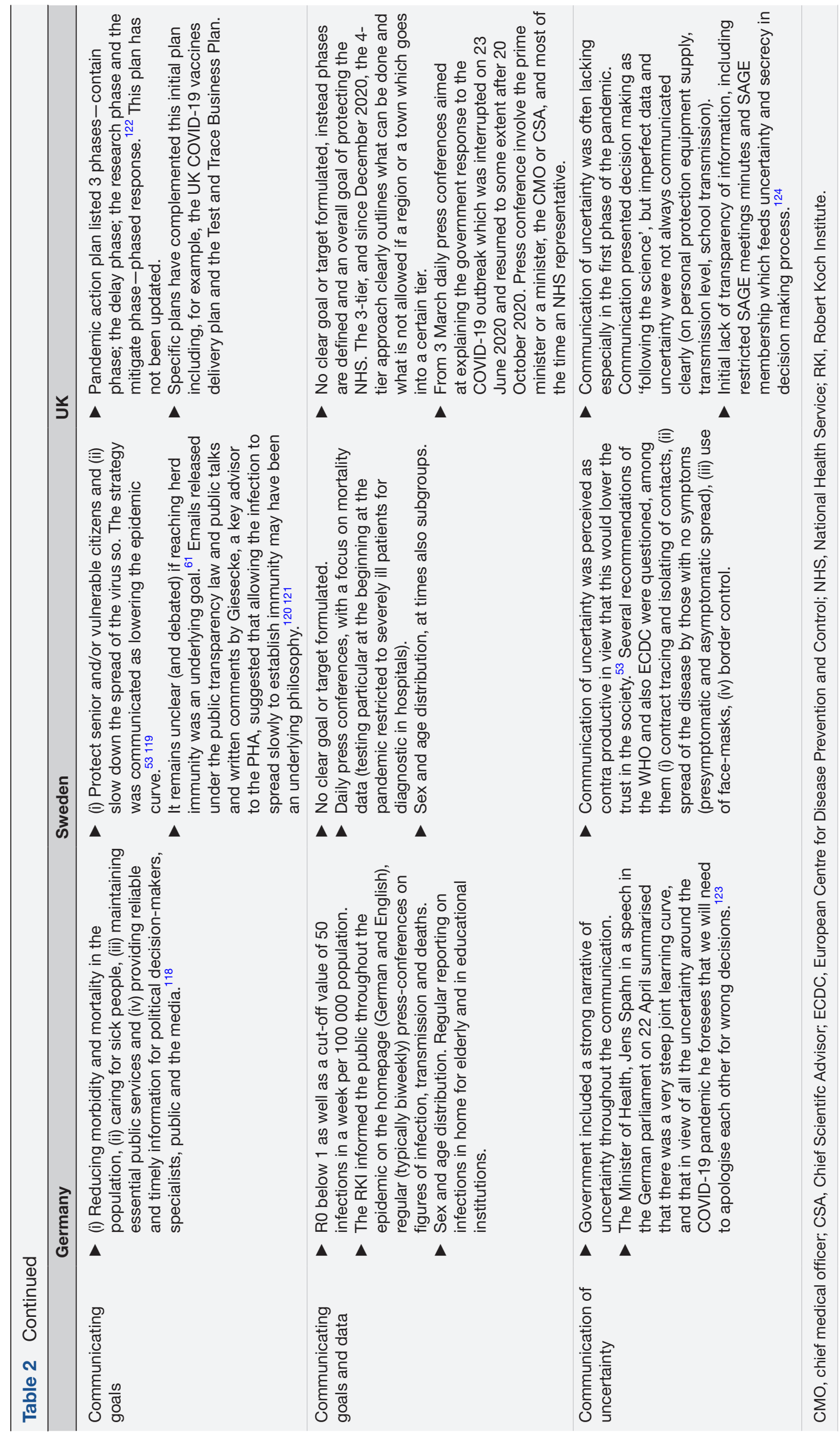




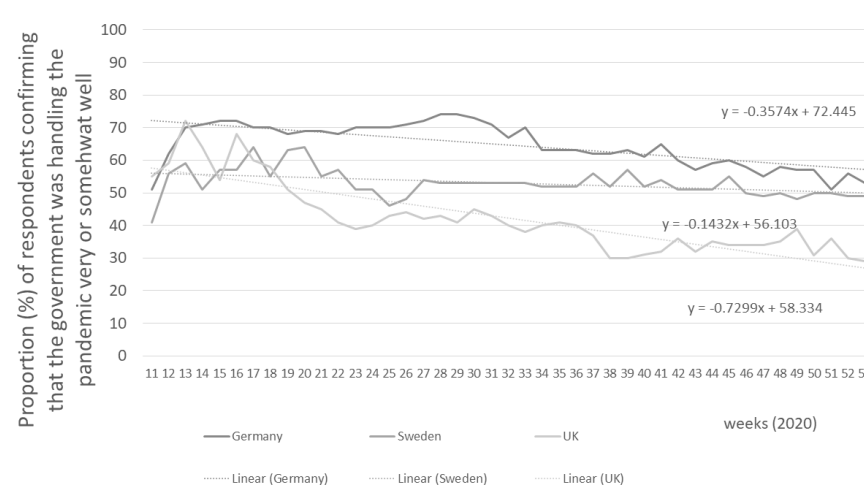

Figure 3 Trust in COVID-19 action by government (YouGov COVID-19 COVID tracker, missing data points imputed).

the second wave. The strongest decline was in the UK $(-0.73$, p value for change $<0.001)$, but trust also tailing off substantially in Germany $(-0.36$, $p$ value for change <0.001). The Swedish trust figures were somewhat more stable after a very early initial decline $(-0.14, \mathrm{p}$ value for change 0.001). The German YouGov COVID-19 tracker trust survey broadly aligns with national polls (online supplemental file 5). Interestingly a larger share of people who were not fully happy with the government response opted for stronger restriction (consistently over $20 \%$ ) than for more relaxed handling throughout 2020 (around 15\%).

\section{DISCUSSION}

Our review of the COVID-19 responses in Germany, Sweden and the UK revealed stark differences which were linked to pre-existing governing structures, the traditional role of academia, experience of crisis management and the communication of uncertainty-all of which have an impact on how much people trusted their government. It will remain difficult to indicate clear successes and failures, however, Germany-although its prepandemic Global Health Security Index was substantially lower than that of Sweden and the UK-indicated convincing aspects of resilience: we highlight diversity and inclusiveness, the strong political and societal debate, and the largely positive involvement of the media to engage with the evolving science and the difficulties to translate science into policies. Sweden dismissed and feared plurality of voices, but trust declined less than in the other countries. The effects of the quasi-abdication of government responsibility on long-term political and social accountability will need to be seen in the future. In the UK, the strong voice of academia held governance accountable but left the public with confusing and rapidly changing public health messages.

\section{Governance and legitimacy of responses}

Crisis management is typically characterised by a concentration of power and a shift to executive decrees. ${ }^{55}$ The concentration of power during the first wave was largely accepted in Germany and UK. In Sweden, similarly, polls suggest that the quasi-abdication of power to a public authority was accepted. ${ }^{56}$ Germany drew on its experience from several crises including the reunification in 1990 and the 2008 financial crisis. ${ }^{57}$ Communication and response have been described as cocreated allowing many actors to debate at national and local level. $^{36}$ The German system seemed to profit from its devolved health systems and decision-making, ${ }^{29}$ although more strongly during the first wave. ${ }^{29} 58$ The seemingly appropriate crisis management in the first wave stands in contrast to the relatively lower score that Germany received in the 2019 Global Health Security Index ${ }^{27}$ compared with Sweden and the UK. This could be interpreted as 'hard resilience is more important than planned public guidance' as Jasanoff et al have suggested. $^{57}$

In Sweden, the PHA de facto led the crisis response. Criticism of crisis management is not new in Sweden: it has followed every crisis, including the Asian Tsunami in 2004 where many Swedish people were killed. ${ }^{59}$ Elisabeth Åsbrink suggested in a much discussed article in March 2020 that Sweden is 'damaged by peace'. ${ }^{60}$ Indeed, the Swedish exceptionalism generated great international media attention, ${ }^{61}$ and to date it remains unclear whether herd immunity was an intended goal of the strategy as proposed by Giesecke. ${ }^{62} 63$ A critical scientific review of the underlying societal and political reasons of the exceptionalism has started however ${ }^{54} 64$ maybe overcoming the challenge that high trust in the government hampers critical debates. ${ }^{65}$

In the UK, the pandemic hit a country which was preoccupied with Brexit. Crisis management was activated relatively early but largely consisted of Parliament deferring most debate and legislative power to the government with its ministries. Later in the pandemic, Parliament became more critical. For example, two House of Commons' Committees have raised serious questions about the government's handling of the test-and-trace policy and the lack of transparency and accountability in its use of data for decision-making. ${ }^{66}$ Parliamentary committees criticised the UK's response as 'hampered by overcentralised, poorly coordinated, and poorly communicated' policies, the side-lining of local providers and failing to work and share data with local authorities, ${ }^{66}$ despite advice early on. ${ }^{67}$ The report also criticised austerity policies in health, with years of underfunding which left local services ill equipped to cope, as well as some technical failures. ${ }^{6768}$

\section{Knowledge and uncertainty: academia's role in and evidence creation}

Uncertainties about the pandemic meant that policymakers needed to find ways to include scientific bodies in decision-making. Both the UK and Germany relied on existing structures. Moreover, members of Germany's government are public health specialists and chancellor Merkel is a scientist herself. Their communications about scientific evidence acknowledged 
uncertainties from the beginning, and consequently the possibility that policies may need to change. In Sweden, the government relied largely on the PHA, with the state epidemiologist being dominant in media and discussion.

In the UK, uncertainty was addressed with a heavy reliance on modelling while largely dismissing its limitations. ${ }^{3169}$ Diversity in shaping public opinion and influencing policies was strongly demanded by an active and vocal science community, illustrated by the creation of alternative bodies (such as Independent SAGE), and strongly worded opinion pieces and blogs and science in scientific and medical journals and the media. These highlighted the importance of academic values and transparency, although they were slow to change government approaches. ${ }^{70}$ However, multiple voices sometimes created confusion for the public, ${ }^{71}$ and government insistence that it was always right may have eroded trust in government, ${ }^{72}$ although this changed following the successful vaccination programme.

In Germany, TV debates are well established and were used for continuous information sharing. In Sweden, only a few TV debate sessions were facilitated. This aligns with the described hesitancy of public debate in Sweden and journalists' relative lack of engagement into scrutiny. Several authors have highlighted the lack of media engagement might have contributed to the limited questioning of the Swedish PHA's handling of the pandemic. ${ }^{54}{ }^{73-75}$ This also might have contributed to the Swedish strategy considered unclear and subject to interpretation. ${ }^{3061}$

\section{Creating trust in the population}

Trust in government increased in those countries in 2020 which were able to almost eliminate COVID-19 such as Australia and New Zealand. ${ }^{76}$ Trust, however, is not linear, but reciprocal. ${ }^{77}$ Some studies indicate a correlation between trust and spread. ${ }^{78}$ High trust might lead to over-reliance on government, thereby decreasing personal efforts to combat the pandemic. ${ }^{79}$ Such over-reliance and greater trust towards the government might have led people in Sweden to take a rather relaxed approach. Mobility data suggest that there are more limited changes in Sweden compared with other European cities during the early first wave. ${ }^{80}$ Other studies appoint to correlations between trust and compliance. ${ }^{81}$ The importance of creating and continuously maintaining trust cannot be sufficiently underscored. Experience of pandemic outbreaks elsewhere shows that even in situations of poor knowledge and knowledge asymmetry, trust-building is an essential component, ${ }^{82}$ and global efforts have sought to address this.

In all three countries, surveys suggest that the public had relatively high levels of trust in their governments at the start of the pandemic, with strong declines in Germany and the UK. The German decline was probably in response to the increasing federal misalignment referred to as a 'patchwork quilt' in the media. While localised actions were a clear strength in the first wave under a unified national approach, ${ }^{29}$ diverging targets and rules in the different states were confusing during the second wave. While a growing share of the public sought tougher measures, the government seemed to be wary of the $10 \%-20 \%$ of the population who were opposed-a response which probably reduced trust further.

The Swedish response has been widely described as a 'close partnership between the government and the society based on mutual trust' ${ }^{83}$ Still, trust was continuously lower than in Germany, but remained more stable. While this approach could be seen as a success, ${ }^{53}$ the longer-term effects of stifling an honest debate remaining unclear.

Trust in the UK declined dramatically early in the pandemic, probably associated with the strong public and academic debate, and in reaction to little transparency in government decision-making. ${ }^{84}$ The multiplicity of views created at times significant debate and controversy, leading to public confusion. ${ }^{85}$

\section{Relevance of the resilience framework}

Our analysis underlines the relevance of our resilience framework highlighting critical government action. It highlighted the need for a balance between critical discourse, diversity, decisive action and clear communication as also recently highlighted. ${ }^{86}$ While the elements of the resilience framework were originally designed to explain health systems resilience, we had to adapt them to include state level action more strongly. We highlight processes, but we do not link the findings to any outcomes, given that the crisis is ongoing, and using measures of COVID-19 infection rates and mortality would create a short-sighted view. For instance, there is insufficient data to allow us to assess how well health systems continued to care for other diseases. ${ }^{87}$

The concept of resilience can be criticised. Interdependence between a crisis and long-term vulnerability is under conceptualised. ${ }^{88}$ The resilience framework from Blanchet et al explicitly aims to highlight how systems transform to create something new and better ${ }^{34}$ while the term resilience has been criticised by others as too static and focused on vulnerability. ${ }^{89}$

\section{Strength and limitations}

We acknowledge the limitations of our review. We constructed the timeline based on published data, but subjectivity remains. We used data on cases, death and testing from trusted sources such ECDC for comparability. To allow a comparative view on citizens' perspectives, we used an international survey. ${ }^{42}$ Responses aligned relatively well in Germany with national polls (online supplemental file 5). Still, simple questions such as whether the government handled the epidemic well obscure the complex reality.

To populate the tables and predefined domains, we used document review methodologies extracting data 
from government homepages for all three countries, complemented by information from the public health agencies of Germany and Sweden. Due to the nature of the data, it was not possible to use search engines and we had to take partly different approaches in the three countries due to the difference in the overall governance and mass media structure. Also, it was not possible to adopt common search terms as would normally be the case in identifying documents for a document analysis, partly because of the language differences between the three countries, and partly because of the language used in relation to COVID-19 evolved very rapidly through 2020.

Depth was assured by the research team living and working in the respective countries (SL in Germany, CH and JS in Sweden, SM-J, SM and NS in the UK, and were native speakers $(\mathrm{CH}$ and SL are German, JS Swedish, SM-J, SM and NS British). Our professional backgrounds are multidisciplinary including in health systems and policy (CH, SM-J, SM and NS) medicine (CH and SL) and governance (JS). CH and SL have a training in the control of infectious diseases. Transparency was assured by careful referencing.

\section{CONCLUSION}

Our cross-country document review highlights critical aspects of governance such as establishing the role of trusted communication with the public and functioning multi-professional and independent science and advisory bodies nationally. Further, we highlight the fine balance between diversity and plurality, the power of decentralised action and the need to communicate clear and understandable goals and objectives.

Germany's federal system and its broad societal support and academic engagement created diversity and pluralism. The localised approach might be an exemplar for a cocreated approach in a crisis-although it has hit its limits in the third wave. The UK's engaged academic institutions informed its strategies and approaches, but the lack of transparency in government decision making undermined trust. In Sweden, high trust in the government might have hampered more critical debates.

Our hypothesis generating analysis suggests that crisis preparedness and resilience framing will need to encompass those governance structures beyond health that enable (i) strong and legitimate leadership facilitating decentralised action and (ii) trusted links to science and advisory bodies. A media structure which is prepared to communicate science and facilitate debate seams to support resilience. Cross-country learning should trump nationalism.

\footnotetext{
Author affiliations

${ }^{1}$ Global Public Health, Karolinska Institutet, Stockholm, Sweden

${ }^{2}$ Disease Control, London School of Hygiene \& Tropical Medicine, London, UK

${ }^{3}$ Institute for risk and disaster reduction, University College London, London, UK

${ }^{4}$ Gesundheitsamt Nuremberg, Nuremberg, Germany

${ }^{5}$ Faculty of Public Health and Policy, London School of Hygiene and Tropical

Medicine Faculty of Public Health and Policy, London, UK
}

${ }^{6}$ School of Global Studies, University of Gothenburg, Goteborg, Västra Götaland, Sweden

${ }^{7}$ London School of Hygiene and Tropical Medicine Faculty of Public Health and Policy, London, UK

Contributors $\mathrm{CH}$, NS, SM and SM-J designed the study. CH, SL, NS, JS, SM and SM-J processed and summarised the data. All authors contributed to the writing and agreed on the final manuscript. $\mathrm{CH}$ is the guarantor of the study and had full access to the data.

Funding Parts of the salary of the first author is covered by a starting grant provided by the Swedish Research Council (grant number 2019-01906).

Competing interests None declared.

Patient consent for publication Not applicable.

Provenance and peer review Not commissioned; externally peer reviewed.

Data availability statement All data relevant to the study are included in the article or uploaded as supplementary information. All information are in public spaces and referenced.

Supplemental material This content has been supplied by the author(s). It has not been vetted by BMJ Publishing Group Limited (BMJ) and may not have been peer-reviewed. Any opinions or recommendations discussed are solely those of the author(s) and are not endorsed by BMJ. BMJ disclaims all liability and responsibility arising from any reliance placed on the content. Where the content includes any translated material, BMJ does not warrant the accuracy and reliability of the translations (including but not limited to local regulations, clinical guidelines, terminology, drug names and drug dosages), and is not responsible for any error and/or omissions arising from translation and adaptation or otherwise.

Open access This is an open access article distributed in accordance with the Creative Commons Attribution 4.0 Unported (CC BY 4.0) license, which permits others to copy, redistribute, remix, transform and build upon this work for any purpose, provided the original work is properly cited, a link to the licence is given, and indication of whether changes were made. See: https://creativecommons.org/ licenses/by/4.0/.

ORCID iD

Claudia Hanson http://orcid.org/0000-0001-8066-7873

\section{REFERENCES}

1 World Health Organization. Weekly epidemiological update - 5 Jan 2021, 2021. Available: https://www.who.int/publications/m/item/ weekly-epidemiological-update-5-january-2021 [Accessed 9 Jan 2021].

2 World Health Organization. Coronavirus disease 2019. Situation Report - 35, 2020. Available: https://www.who.int/docs/defaultsource/coronaviruse/situation-reports/20200224-sitrep-35-covid19.pdf?sfvrsn=1ac4218d_2 [Accessed 12 Apr 2020].

3 Leung G. Nowcasting COVID-19 for public health control: learning from the Chinese experience for global preparedness, 2020. Available: https://panopto.Ishtm.ac.uk/Panopto/Pages/Viewer. aspx?id=83ba0783-b1ce-4053-aaa5-ab6600da76d8

4 World Health Organization. WHO-China joint mission on coronavirus disease 2019 (COVID-19), 2020. Available: https:// www.who.int/publications-detail/report-of-the-who-china-jointmission-on-coronavirus-disease-2019-(covid-19) [Accessed $14 \mathrm{Apr}$ 2020].

5 Verity R, Okell LC, Dorigatti I, et al. Estimates of the severity of coronavirus disease 2019: a model-based analysis. Lancet Infect Dis 2020;20:669-77.

6 Ioannidis JPA. Infection fatality rate of COVID-19 inferred from seroprevalence data. Bull World Health Organ 2021;99:19-33.

7 O'Driscoll M, Ribeiro Dos Santos G, Wang L, et al. Age-Specific mortality and immunity patterns of SARS-CoV-2. Nature 2021;590:140-5.

8 Haldane V, Ong S-E, Chuah FL-H, et al. Health systems resilience: meaningful construct or catchphrase? Lancet 2017;389:1513.

9 Fauci AS, Lane HC, Redfield RR. Covid-19 - Navigating the Uncharted. N Engl J Med Overseas Ed 2020;382:1268-9.

10 ECDC. Transmission of COVID-19 (latest uptade 30 June 2020), 2020. Available: https://www.ecdc.europa.eu/en/covid-19/latestevidence/transmission [Accessed 24 Nov 2020].

11 SAGE. Children's Task and Finish Group: update to 4th Nov 2020 paper on children, schools and transmission, 2020. Available: 
https://assets.publishing.service.gov.uk/government/uploads/ system/uploads/attachment_data/file/948617/s0998-tfc-updateto-4-november-2020-paper-on-children-schools-transmission.pdf [Accessed 9 Jan 2021].

12 European Centre for Disease Prevention and Control. COVID-19 in children and the role of school settings in transmission - first update 23 Dec, 2020. Available: https://www.ecdc.europa.eu/ en/publications-data/children-and-school-settings-covid-19transmission [Accessed 9 Jan 2021].

13 Polack FP, Thomas SJ, Kitchin N, et al. Safety and efficacy of the BNT162b2 mRNA Covid-19 vaccine. N Engl J Med 2020;383:2603-15.

14 Christensen T, Lægreid P. Balancing governance capacity and legitimacy - how the Norwegian government handled the COVID-19 crisis as a high performer. Public Adm Rev 2020;80:774-9.

15 Hanefeld J, Mayhew S, Legido-Quigley H, et al. Towards an understanding of resilience: responding to health systems shocks. Health Policy Plan 2018;33:355-67.

16 Richards P. Ebola and COVID-19 in Sierra Leone: comparative lessons of epidemics for Society. J Glob Hist 2020;15:493-507.

17 Ebola Gbalo Research Group. Responding to the Ebola virus disease outbreak in DR Congo: when will we learn from Sierra Leone? Lancet 2019;393:2647-50.

18 Barasa EW, Cloete K, Gilson L. From Bouncing back, to nurturing emergence: reframing the concept of resilience in health systems strengthening. Health Policy Plan 2017;32:iii91-4.

19 Saulnier DD, Hean H, Thol D, et al. Staying afloat: community perspectives on health system resilience in the management of pregnancy and childbirth care during floods in Cambodia. BMJ Glob Health 2020;5:e002272.

20 Ling EJ, Larson E, Macauley RJ, et al. Beyond the crisis: did the Ebola epidemic improve resilience of Liberia's health system? Health Policy Plan 2017;32:iii40-7.

21 Saulnier DD, Blanchet K, Canila C, et al. A health systems resilience research agenda: moving from concept to practice. BMJ Glob Health 2021;6:e006779.

22 Meessen B. Health system governance: welcoming the reboot. BMJ Glob Health 2020;5:e002404.

23 Topp SM. Power and politics: the case for linking resilience to health system governance. BMJ Glob Health 2020;5:e002891.

24 Islam N, Shkolnikov VM, Acosta RJ, et al. Excess deaths associated with covid-19 pandemic in 2020: age and sex disaggregated time series analysis in 29 high income countries. BMJ 2021;373:n1137.

25 Bloomberg. The best and worst places to be, 2021. Available: https://www.bloomberg.com/graphics/covid-resilience-ranking/ [Accessed 9 Aug 2021].

26 Kaiser M, Chen AT-Y, Gluckman P. Should policy makers trust composite indices? A commentary on the pitfalls of inappropriate indices for policy formation. Health Res Policy Syst 2021;19:40.

27 Cameron E, Nuzzo J, Bell J. Global health security index. building collective action and accountability, 2019. Available: https://www. ghsindex.org/\#l-section-map [Accessed 28 Mar 2021].

28 Vinke K, Gabrysch S, Paoletti E, et al. Corona and the climate: a comparison of two emergencies. Global Sustainability 2020;3:e25.10.1017/sus.2020.20

29 Han E, Tan MMJ, Turk E, et al. Lessons learnt from easing COVID-19 restrictions: an analysis of countries and regions in Asia Pacific and Europe. Lancet 2020;396:1525-34.

30 Andersson S, Aylott N. Sweden and coronavirus: Unexceptional exceptionalism. Soc Sci 2020;9:232.

31 Ferguson N, Laydon D, Nedjati G. Report 9 - Impact of nonpharmaceutical interventions (NPIs) to reduce COVID-19 mortality and healthcare demand, 2020. Available: https://www.imperial. ac.uk/media/imperial-college/medicine/sph/ide/gida-fellowships/ Imperial-College-COVID19-NPI-modelling-16-03-2020.pdf [Accessed 4 Jan 2021].

32 Farrar J, Ahuja A. Spike: The Virus vs. The People - the Inside Story. London, UK: Profile Books Ltd, 2021.

33 European Centre for Disease Prevention and Control. Situation update on COVID-19, 2020. Available: https://www.ecdc.europa. eu/en/covid-19/situation-updates [Accessed 10 Jan 2021].

34 Blanchet K, Nam SL, Ramalingam B, et al. Governance and capacity to manage resilience of health systems: towards a new conceptual framework. Int J Health Policy Manag 2017;6:431-5.

35 Ansell C, Sørensen E, Torfing J. The COVID-19 pandemic as a game changer for public administration and leadership? the need for robust governance responses to turbulent problems. Public Management Review 2021;23:949-60.
36 Marten R, El-Jardali F, Hafeez A, et al. Co-producing the covid-19 response in Germany, Hong Kong, Lebanon, and Pakistan. BMJ 2021;372:n243

37 Frey B. Document analysis. In: Frey BB, ed. The SAGE encyclopedia of educational research, measurement, and evaluation. SAGE, 2018.

38 Robert Koch Institute. Robert Koch Institute: mission statement, 2000. Available: https://www.rki.de/EN/Content/Institute/Mission Statement/Mission_Statement_node.html [Accessed 25 Apr 2020].

39 Public Health Agency. Our mission - to strengthen and develop public health., 2020. Available: https://www.folkhalsomyndigheten. se/the-public-health-agency-of-sweden/ [Accessed 8 Jan 2021].

40 Government of the United Kingdom. Coronavirus (COVID-19), 2020. Available: https://www.gov.uk/coronavirus [Accessed 8 Jan 2021].

41 COVID-19 Government Response. COVID-19: government response stringency index, 2020. Available: https:// ourworldindata.org/grapher/covid-stringency-index [Accessed 8 Jan 2021].

42 YouGov. COVID-19: government handling and confidence in health authorities., 2020. Available: https://yougov.co.uk/topics/ international/articles-reports/2020/03/17/perception-governmenthandling-covid-19 [Accessed 6 Feb 2021].

43 Vogel G. 'It's been so, so surreal.' Critics of Sweden's lax pandemic policies face fierce backlash, 2020. Available: https://www. sciencemag.org/news/2020/10/it-s-been-so-so-surreal-criticssweden-s-lax-pandemic-policies-face-fierce-backlash [Accessed 20 Oct 2020]

44 Institute for Government. Coronavirus and devolution, 2020. Available: https://www.instituteforgovernment.org.uk/explainers/ coronavirus-and-devolution [Accessed 6 Mar 2021].

45 House of commons science and technology Committee. oral evidence: UK science, research and technology capability and influence in global disease outbreaks, HC 136, 2020. Available: https://committees.parliament.uk/oralevidence/761/pdf/ [Accessed 11 Sep 2021]

46 Public Health Agency. The Public Health Agency of Sweden's work with COVID-19, 2020. Available: https://www. folkhalsomyndigheten.se/the-public-health-agency-of-sweden/ communicable-disease-control/covid-19/the-public-health-agencyof-swedens-work-with-covid-19/ [Accessed 9 Jan 2020]

47 NDR.de - Nachrichten. Corona-Podcast: Alle Folgen in Der Übersicht, 2020. Available: https://www.ndr.de/nachrichten/info/ Corona-Podcast-Alle-Folgen-in-der-Uebersicht,podcastcoronavir us134.html [Accessed 26 Apr 2020].

48 NDR. Grimme online awards für Drosten-Podcast und STRG_F. Available: https://www.ndr.de/nachrichten/info/Grimme-OnlineAwards-fuer-Drosten-Podcast-und-STRGF,grimmeonlineaward102. html [Accessed 20 Feb 2021].

49 Nielsen R, Kalogeropoulos A, Fletcher R. The tenth factsheet of the UK COVID-19 news and information project, 2020. Available: https://reutersinstitute.politics.ox.ac.uk/most-uk-say-news-mediahave-helped-them-respond-covid-19-third-say-news-coveragehas-made-crisis [Accessed 6 Mar 2021].

50 National Audit Office. The government's approach to test and trace in England - interim report. London: Report by the Controller and Auditor General, 2020.

51 Priesemann V, Brinkmann MM, Ciesek S, et al. Calling for panEuropean commitment for rapid and sustained reduction in SARSCoV-2 infections. Lancet 2021;397:92-3.

52 Welt. Jens Spahn "Wir werden viel verzeihen muessen" Speech in the German parliament Welt. Panorama. Available: https://www. welt.de/vermischtes/article207443999/Das-Update-zur-CoronaKrise-Wir-werden-viel-verzeihen-muessen-sagt-Jens-Spahn.html,; [Accessed 22 Apr 2020].

53 Lindström M. The COVID-19 pandemic and the Swedish strategy: epidemiology and postmodernism. SSM Popul Health 2020;11:100643.

54 Lindström M. The new Totalitarians: the Swedish COVID-19 strategy and the implications of consensus culture and media policy for public health. SSM Popul Health 2021;14:100788.

55 Bekker M, Ivankovic D, Biermann O. Early lessons from COVID-19 response and shifts in authority: public trust, policy legitimacy and political inclusion. Eur J Public Health 2020;30:854-5.

56 Bylund PL, Packard M. Separation of Power and Expertise: Evidence of the Tyranny of Experts in Sweden's COVID-19 Responses. South Econ J 2021:1-20.

57 Jasanoff S, Hilgartner S, et al, CompCoRe Research Team. Comparative Covid response: crisis, knowledge, politics. interim report: Harvard Kennedy school. John F. Kennedy School of Government, 2021. 
58 Wieler L, Rexroth U, Gottschalk R. Emerging COVID-19 success story: Germany's strong enabling environment. In: Emerging COVID-19 success story: Germany's strong enabling environment Our World in Data. Exemplars in Global Health,, 2020.

59 Regeringen. Sverige och tsunamin - granskning och förslag, 2005. Available: https://www.regeringen.se/rattsliga-dokument/statensoffentliga-utredningar/2005/12/sou-2005104/ [Accessed 4 Feb 2021]

60 Åsbrink E. Coronakrisen visar ATT Sverge är ett fredsskadat land, 2020. Available: https://www.dn.se/kultur-noje/elisabeth-asbrinkcoronakrisen-visar-att-sverige-ar-ett-fredsskadat-land/ [Accessed 7 Feb 2021].

61 Irwin RE. Misinformation and de-contextualization: international media reporting on Sweden and COVID-19. Global Health 2020;16:62

62 Giesecke J. The invisible pandemic. The Lancet 2020;395:e98.

63 LockdownTV. Why lockdowns are the wrong policy - Swedish expert Prof Johan Giesecke. 17. UnHeard LockdownTV, 2020

64 Giritli Nygren K, Olofsson A. Swedish exceptionalism, herd immunity and the welfare state: a media analysis of struggles over the nature and legitimacy of the COVID-19 pandemic strategy in Sweden. Current Sociology 2021;69:529-46.

65 Berggren H, Trägårdh L. Är svensken människa?: gemenskap och oberoende I det moderna Sverige Nordstedts, 2006.

66 House of Commons Public Administration and Constitutional Affairs Committee. Government transparency and accountability during Covid 19: the data underpinning decisions. London, 2021.

67 UK Parliament. A critical juncture for public services: lessons from covid-19, 2020. Available: https://committees. parliament.uk/ committee/430/public-services-committee/publications [Accessed $21 \mathrm{Feb} 2021$ ]

68 Daly M. COVID -19 and care homes in England: What happened and why? Soc Policy Adm 2020;54:985-98.

69 Rhodes T, Lancaster K, Lees S, et al. Modelling the pandemic: attuning models to their contexts. BMJ Glob Health 2020;5:e002914.

70 Abbasi K. Covid-19: politicisation, "corruption," and suppression of science. BMJ 2020;371:m4425.

71 Sanders KB. British government communication during the 2020 COVID-19 pandemic: learning from high reliability organizations. Church, Communication and Culture 2020;5:356-77.

72 Nielsen R, Fletcher R, Kalogeropoulos A. Communications in the coronavirus crisis: lessons for the second wave, 2020. Available: https://reutersinstitute.politics.ox.ac.uk/communicationscoronavirus-crisis-lessons-second-wave [Accessed 9 Jan 2021].

73 Ghersetti M, Odén T. Coronapandemin våren 2020. En undersökning av nyheter och opinion, 2021. Available: https://www. gu.se/sites/default/files/2021-03/Cornapandemin\%20va\%CC\% 8Aren\%202020.pdf [Accessed 8 Mar 2021].

74 Vogel G. Sweden's gamble. Science 2020;370:159-63.

75 Bjurwald L. Opinion: are Swedish reporters lousy at asking followup questions? The Local, 2020.

76 Taplin R, Gauld R, Goldfinch S. Trust in government increased during the Covid-19 pandemic in Australia and New Zealand. Aust J Public Adm 2021.

77 Harring N, Jagers SC, Löfgren Åsa. COVID-19: large-scale collective action, government intervention, and the importance of trust. World Dev 2021;138:105236.

78 Min J. Does social trust slow down or speed up the transmission of COVID-19? PLoS One 2020;15:e0244273.

79 Woelfert FS, Kunst JR. How political and social trust can impact social distancing practices during COVID-19 in unexpected ways. Front Psychol 2020;11:572966.

80 Vannoni M, McKee M, Semenza JC, et al. Using volunteered geographic information to assess mobility in the early phases of the COVID-19 pandemic: a cross-city time series analysis of 41 cities in 22 countries from March 2nd to 26th 2020. Global Health 2020;16:85

81 Siegrist M, Luchsinger L, Bearth $A$. The impact of trust and risk perception on the acceptance of measures to reduce COVID-19 cases. Risk Analysis 2021;41:787-800.

82 Ryan MJ, Giles-Vernick T, Graham JE. Technologies of trust in epidemic response: openness, reflexivity and accountability during the 2014-2016 Ebola outbreak in West Africa. BMJ Glob Health 2019;4:e001272.

83 Kavaliunas A, Ocaya P, Mumper J, et al. Swedish policy analysis for Covid-19. Health Policy Technol 2020;9:598-612.

84 Fletcher R, Kalogeropoulos A, Simon F. Information inequality in the UK coronavirus communications crisis, 2020. Available: https://reutersinstitute.politics.ox.ac.uk/information-inequalityuk-coronavirus-communications-crisis [Accessed 6 Mar 2021].
85 Clarke L. Why scientists fear the "toxic" Covid-19 debate, 2020. Available: https://www.newstatesman.com/science-tech/ coronavirus/2020/10/why-scientists-fear-toxic-covid-19-debate [Accessed 6 Mar 2021].

86 Haldane V, De Foo C, Abdalla SM, et al. Health systems resilience in managing the COVID-19 pandemic: lessons from 28 countries. Nat Med 2021;27:964-80.

87 Lazarus JV, Binagwaho A, El-Mohandes AAE, et al. Keeping governments accountable: the COVID-19 assessment Scorecard (COVID-SCORE). Nat Med 2020;26:1005-8.

88 Thomas S, Sagan A, Larkin J. European Observatory policy Briefs, 2020. Available: https://eurohealthobservatory.who.int/ publications/policy-briefs?publicationtypes=bddae111-76ee4e8a-93e0-18a7cc75d0ee\&publicationtypes-hidden=true [Accessed 28 Mar 2021].

89 Fletcher D, Sarkar M. Psychological resilience a review and critique of definitions, concepts, and theory. European Psychologist 2013;18:12-23.

90 Deutscher Bundestag. Gesetzgebungszuständigkeiten von Bund und Ländern. Available: https://www.bundestag.de/parlament/ aufgaben/gesetzgebung_neu/gesetzgebung/bundesstaatsprinzip255460 [Accessed $24 \mathrm{Apr} 2020$ ].

91 OECD. OECD survey on the science and innovation policy responses to coronavirus COVID-19. 2020, 2020. Available: https:// stip.oecd.org/Covid.html [Accessed 5 Dec 2020].

92 Regeringen. Regeringskansliets krishantering, 2019. Available: https://www.regeringen.se/regeringens-politik/krisberedskap/ regeringskansliets-krishantering/ [Accessed 4 Feb 2021].

93 Riksdag S. En Tillfällig covid-19-lag., 2021. Available: https://data. riksdagen.se/fil/7373001A-3CBF-4D27-985A-7DBA1CB0E6F1 [Accessed 8 Mar 2021].

94 Regeringskansliet. Covid-19-lagen gör det möjligt ATT införa effektivare smitt-skydds-åtgärder, 2021. Available: https://www. regeringen.se/artiklar/2021/01/lattlast-om-covid-19-lagenpandemi-lagen/ [Accessed 8 Mar 2021].

95 Robert Koch Institute. Infektionsschutzgesetz, 2020. Available: https://www.rki.de/DE/Content/Infekt/lfSG/ifsg_node.html [Accessed 9 Jan 2021].

96 Ludvigsson JF. The first eight months of Sweden's COVID-19 strategy and the key actions and actors that were involved. Acta Paediatr 2020;109:2459-71.

97 Government of the United Kingdom. Coronavirus act 2020, 2020. Available: https://www.legislation.gov.uk/ukpga/2020/7/contents/ enacted [Accessed 6 Dec 2020].

98 Norberg J. How Sweden is responding to the coronavirus. YouTube, 2020.

99 Government of the United Kingdom. Transparency data, 2020. Available: https://www.gov.uk/government/publications/scientificadvisory-group-for-emergencies-sage-coronavirus-covid-19response-membership/list-of-participants-of-sage-and-relatedsub-groups

100 Helmholz. Stellungnahme der Helmholtz-Initiative „Systemische Epidemiologische Analyse der COVID-19-Epidemie, 2020. Available: https://www.helmholtz.de/fileadmin/user upload/01 forschung/ Helmholtz-COVID-19-Papier 02.pdf [Accessed 25 Apr 2020].

101 Leopoldina.. Coronavirus: Nationalakademie Leopoldina legt dritte Ad-hoc-Stellungnahme VOR, 2020 [Accessed 25 Apr 2020].

102 Etikrat D. Solidarität und Verantwortung in Der Corona-Krise. AdHoc-Empfehlung, 2020 [Accessed 26 Apr 2020].

103 Science forum COVID-19, 2020. Available: https://vetcov19.se/ [Accessed $21 \mathrm{Mar}$ 2021].

104 indie_SAGE, 2020. Available: https://www.independentsage.org/ [Accessed 9 Jan 2021].

105 Streeck H, Schulte B, Kümmerer BM, et al. Infection fatality rate of SARS-CoV2 in a super-spreading event in Germany. Nat Commun 2020;11:5829.

106 Ministry of Health and Social Affairs. Mats Melin to chair CVID-19 inquiry in Sweden, 2020. Available: https://www.government.se/ press-releases/2020/06/mats-melin-to-chair-covid-19-inquiry-insweden/

107 Melin M, Ahlbäck Öberg S AE. The corona Commission. elderly care during the pandemic. Ministry of health and social Affairs, summary of SOU 2020:80, 2020. Available: https://www. government.se/4af26a/contentassets/2b394e1186714875bf29 991b4552b374/summary-of-sou-2020 80-elderly-care-during-thepandemic.pdf [Accessed 2 Jan 2021].

108 Scherman J. Svenskt rekord I direktsändningar - VaD gör det Med journalistiken? 2021. Available: https://www.dagensmedia. se/medier/dagspress/jan-scherman-svenskt-rekord-idirektsandningar-vad-gor-det-med-journalistiken/ [Accessed $8 \mathrm{Mar}$ 2021]. 
109 Böhmer MM, Buchholz U, Corman VM, et al. Investigation of a COVID-19 outbreak in Germany resulting from a single travel-associated primary case: a case series. Lancet Infect Dis 2020;20:920-8.

110 Rothe C, Schunk M, Sothmann P, et al. Transmission of 2019-nCoV infection from an asymptomatic contact in Germany. N Engl J Med Overseas Ed 2020;382:970-1.

111 Parliament. Test, track and trace, 2020. Available: https:// publications.parliament.uk/pa/cm5801/cmselect/cmpubacc/932/ 93202.htm [Accessed 13 Mar 2021].

112 Walker AS, Bell I, Diamond I. Study protocol: incidence of SARSCoV-2 infection and prevalence of immunity to SARS-CoV-2 in the UK general population as assessed through repeated crosssectional household surveys with additional serial sampling and longitudinal follow-up -an office of national statistics survey, 2020. Available: https://www.ndm.ox.ac.uk/files/coronavirus/covid-19infection-survey/protocol-covid-infection-survey-2020-04-20-v1-0clean-with-ethics-ref.pdf [Accessed 12 Dec 2020].

113 Imperial College London. Real-Time assessment of community transmission (react) study, 2020. Available: https://www.imperial.ac uk/medicine/research-and-impact/groups/react-study/ [Accessed 12 Dec 2020].

114 Riley S, Atchison C, Ashby D. REal-time Assessment of Community Transmission (REACT) of SARS-CoV-2 virus: Study protocol [version 1 peer review: 1 approved], 2020.

115 Bundesministerium fuer Gesundheit. Zusammen gegen Corona: \#WirBleibenZuhause., 2020. Available: https://twitter.com/bmg_ bund/status/1240315836369440768?lang=en [Accessed 8 Jan 2021].

1161177 Health Service. Om Covid-19 - coronavirus, 2020. Available: https://www.1177.se/Stockholm/sjukdomar-besvar/lungor-ochluftvagar/inflammation-och-infektion-ilungor-och-luftror/omcovid-19-coronavirus/laget-i-stockholm-just-nu/ [Accessed 8 Jan 2021].
117 Public Health Agency. Can COVID-19 be transmitted from a person who is infected but does not experience any symptoms? Stockholm: Public Health Agency, 2020.

118 Robert Koch Institute. Vorvereitungen aud Massnahmen in Deutschland, version 1.0 (stand 04.03.2020), Ergänzung zum Nationalen Pandemieplan - COVID-19 - neuartige Coronaviruserkrankung, 2020. Available: https://www.rki.de/ DE/Content/InfAZ/N/Neuartiges_Coronavirus/Ergaenzung Pandemieplan_Covid.pdf?_blob=publicationFile [Accessed $12 \mathrm{Apr}$ 2020].

119 Prime Ministers's Office. Strategy in response to the COVID-19 pandemic., 2020. Available: https://www.government.se/articles/ 2020/04/strategy-in-response-to-the-covid-19-pandemic/ [Accessed 12 Dec 2020]

120 Sörensen JS. Terror in utopia. Socioloski Pregled / Sociological Review Refer LIV, 2020: 961-1007.

121 Vogel G. 'It's been so, so surreal.' Critics of Sweden's lax pandemic policies face fierce backlash, 2020. Available: https://www. sciencemag.org/news/2020/10/it-s-been-so-so-surreal-criticssweden-s-lax-pandemic-policies-face-fierce-backlash [Accessed 8 Mar 2021].

122 Government of the United Kingdom. Policy paper. coronavirus action plan: a guide to what you can expect across the UK our response to the current coronavirus outbreak: current planning, 2020. Available: https://www.gov.uk/government/publications/ coronavirus-action-plan/coronavirus-action-plan-a-guide-to-whatyou-can-expect-across-the-uk [Accessed 9 Jan 2021].

123 Jens Spahn "Wir werden viel verzeihen muessen" Speech in the German parliament Welt. Panorama. Available: https://www.welt. de/vermischtes/article207443999/Das-Update-zur-Corona-KriseWir-werden-viel-verzeihen-muessen-sagt-Jens-Spahn.html,; [Accessed 22 Apr 2020].

124 Newton K. Government communications, political trust and compliant social behaviour: the politics of Covid-19 in Britain. Polit Q 2020;91:502-13. 